N. TSubanova, D. ZhuREnKo

National University of Pharmacy

\title{
PhaRMaCOLOGICAL EFFECT OF A NEW GEL, WHICH CONTAINS OAK BARK EXTRACT AND ALOE EXTRACT UNDER THE CONDITION OF EXPERIMENTAL STOMATITIS IN RATS
}

Topicality. Aloe extract and oak bark extract are considered to be the most perspective medicinal raw materials in new drug development for dental practice.

Aim. Aloe extract and oak bark extract are promising medicines for the development of a new drug for dental practice.

Materials and methods. Experimental stomatitis was reconstituted by a one-time 5-second application with a cotton swab filled with a $10 \%$ solution of sodium hydroxide. In the blood were investigated content of leukocytes and rate of erythrocyte sedimentation rate (ESR). The activity of catalase measured in tongue homogenate, and determined the content of reduced glutathione and thiobarbituric acid reagents. Metrogyl Denta was used as a comparison drug.

Results and discussion. It was established that the new gel is likely to exceed the Metrogyl Denta for a decrease in the clinical parameters of stomatitis (hyperemia, edema, erosive-necrotic changes). The gel which contains oak bark extract and aloe extract have anti-inflammatory effect, reduces leukocytosis and ESR. The new gel have significant advantages over Metrogyl Denta, by high antioxidant effect, which is determined by the activity of catalase and indicators of reduced glutathione and thiobarbituric acid reagents.

Conclusions. The new gel, which contains oak bark extract and aloe extract, is found to be an effective remedy for the treatment of experimental stomatitis, can be considered promising for further research and implementation into medical practice.

Key words: gel; oak bark extract; aloe extract; stomatitis

Н. А. Цубанова, Д. С. Журенко

Фармакологічна дія нового гелю, що містить екстракт кори дуба і екстракт алое, в умовах експериментального стоматиту у щурів

Актуальність. Екстракт алое та екстракт кори дуба - це перспективна лікарська сировина, $є$ оптимальними компонентами для розробки нового лікарського препарату для стоматологічної практики

Мета дослідження. Вивчення ефективності нового гелю, що містить у своєму складі густий екстракт кори дуба та сухий екстракт алое за умов експериментального стоматиту.

Матеріали та методи. Дослідження фармакологічної активності нового гелю, що містить екстракт кори дуба та екстракт алое за умов експериментального стоматиту, який відтворювали одноразовою 5-ти секундною аплікацією ватним тампоном, просоченим 10 \% розчином натрію гідроксиду. У крові досліджували вміст лейкоцитів, показник швидкості зсідання еритроцитів (ШОЕ). У гомогенаті язика вимірювали активність каталази, визначали вміст відновленого глутатіону та реактантів тіобарбітурової кислоти. Як препарат порівняння використовували Метрогіл Дента.

Результати та їх обговорення. Встановлено, що новий гель вірогідно перевищує Метрогіл Дента за зниженням клінічних показників стоматиту (гіперемії, набряку, ерозивно-некротичних змін). Гель, що містить екстракт кори дуба та екстракт алое, чинить виражену протизапальну дію, знижує лейкоцитоз та ШОЕ. Значними перевагами нового гелю $є$ значна антиоксидантна дія на відміну від гелю Метрогіл Дента, що встановлено за впливом на активність каталази та показники відновленого глутатіону та реактантів тіобарбітурової кислоти.

Висновки. Новий гель, що містить екстракт кори дуба та екстракт алое, який, як встановлено, є ефективним засобом для лікування експериментального стоматиту, можна вважати перспективним для подальшого дослідження та впровадження у медичну практику.

Ключові слова: гель; екстракт кори дуба; екстракт алое; стоматит

\section{Н. А. Цубанова, Д. С. Журенко}

Фармакологическое действие нового геля, содержащего экстракт коры дуба и экстракт алоэ, в условиях экспериментального стоматита у крыс

Актуальность. Экстракт алоэ и экстракт коры дуба - это перспективное лекарственное сырье, являются оптимальными компонентами для разработки нового лекарственного препарата для стоматологической практики.

Цель исследования. Изучение эффективности нового геля, содержащего в своем составе густой экстракт коры дуба и сухой экстракт алоэ в условиях экспериментального стоматита.

Материалы и методы. Исследование фармакологической активности нового геля, содержащего экстракт коры дуба и экстракт алоэ в условиях экспериментального стоматита, который воспроизводили одноразовой 5-ти секундной аппликацией ватным тампоном, пропитанным 10 \% раствором натрия гидроксида. В крови исследовали содержание лейкоцитов, показатель скорости оседания эритроцитов (СОЭ). В гомогенате языка вымеряли активность каталазы, определяли содержание восстановленного глутатиона и реактантов тиобарбитуровой кислоты. В качестве препарата сравнения применялся Метрогил Дента. 
Результаты и их обсуждение. Установлено, что новый гель достоверно превосходит Метрогил Дента по снижению клинических показателей стоматита (гиперемии, отека, эрозивно-некротических изменений). Гель, содержащий экстракт коры дуба и экстракт алоэ, оказывает выраженное противовоспалительное действие, снижает лейкоцитоз и СОЭ. Значительным преимуществом нового геля является выраженное антиоксидантное действие в отличие от геля Метрогил Дента, что установлено по влиянию на активность каталазы и показатели восстановленного глутатиона и реактантов тиобарбитуровой кислоты.

Выводы. Новый гель, содержащий экстракт коры дуба и экстракт алоэ, который, как установлено, является эффективным средством для лечения экспериментального стоматита, можно считать перспективным для дальнейшего исследования и внедрения в медицинскую практику.

Ключевые слова: гель; экстракт коры дуба; экстракт алоэ; стоматит

\section{INTRODUCTION}

Stomatitis is one of the most urgent problems in dental practice, along with periodontitis, in the structure of inflammatory diseases of the oral cavity [1].

To date, in many countries there is a steady tendency to increase of the number of inflammatory diseases of the oral cavity. The prevalence of various destructive inflammatory diseases of the mucous membrane of the oral cavity and paradont is in the range of 75-90\% among children and reaches $95 \%$ among the adult population [2].

In a clinical study by Kansky A. A. (2018) [3], which was conducted at 2395 healthy men (904) and women (1491) in accordance with WHO standards, found that 645 patients ( $27 \%$ ) had inflammatory lesions of the oral mucosa, among which the dominant position was occupied by stomatitis, gingivitis, aphthous ulcers. In general, these epidemiological data indicate the need for specific health strategies for the prevention, diagnosis and treatment of mucosal lesions of the oral cavity.

It is also important to correlate the stomatitis with other chronic diseases. According to Kato S. (2017) [4], it is also proven that stomatitis may also increase the risk of local and systemic infection and significantly impair the patient's quality of life.

It has been proved that in the pathogenesis of stomatitis, the activation of lipid peroxidation processes have a leading role, which causes an increase in apoptosis and a decrease in proliferation with the simultaneous release of cytokines derived from keratinocytes, and triggers a cascade of inflammation [5]. The study by Zhang Z. (2017) [6] confirmed that the enzymatic antioxidant system was weakened in patients with stomatitis, which plays a decisive role in the pathogenesis.

Standard therapy for stomatitis is aimed primarily at the elimination of pathogenic microflora and reduction of inflammation processes, but practically does not affect the balance of the system of lipid peroxidation (LPO) - antioxidant protection (AOP), which plays a decisive role in the pathogenesis of this pathology. Actual questions of medicine are not only the optimization of therapy of stomatitis, but also the development of new drugs with a powerful antioxidant effect.

Clinically proven (Nasry S. A., 2016) [7] that plant extracts exhibit high efficacy in the treatment of stomatitis and normalize the flow to the LPO-AOP balance.

According to the literature, aloe are considered as a promising for the development of an effective dental gel. According to a study by Sahebjamee M. (2015) [8], the use of aloe extract in stomatitis is not inferior to a known anti-inflammatory agent benzidamine. It should be noted that unlike benzidamine, the aloe extract does not have side effects.

According to Mansouri P. (2016), [9] the use of aloe extract by patients significantly reduces the clinical manifestations of stomatitis. In the case of biologically active oak bark, the study of Shimpi N. (2016) noted the positive effect of oak drugs on oral cavity in the context of infectious diseases.

Aloe extract and oak bark extract can be considered as the optimal components for the development of a new dental drug. Scientists of NUPh, under the direction of prof. Hochlenkova N. V., was developed a drug in the form of a gel of such a composition.

The aim is to study the effectiveness of a new gel which contains an oak bark thick extract and aloe dry extract in the conditions of experimental stomatitis.

\section{MATERIALS AND METHODS}

Experimental stomatitis was reconstituted by a one-time 5 -second application with a cotton swab $10 \%$ sodium hydroxide solution to the mouthpiece between the lower lip and the cutter of the mandible in rats [10]. The experiment was conducted on 32 male rats, with weight 180-210 g. Animals, at which was caused stomatitis, were divided into 4 groups: 1st group - intact control (IC); 2nd group animals with reproduced model of stomatitis - control pathology (CP); group 3 - animals that were treated with a new gel (NG), which contains oak bark extract and aloe extract on the background of model pathology; group 4 animals treated with the Metrogyl Denta comparison drug (manufactured by Unic Pharmacist Laboratories India) (MD). The investigated drugs were placed on the affected area of the mucous membrane with a cotton swab 2 times a day for 10 days in the form of applications.

Clinical parameters were recorded at the course of experimental stomatitis in points (hyperemia), namely: lower lip, gums and tooth-clear papillae, were performed by observation in points $(\mathrm{p})$ : hyperemia - absent $(0 \mathrm{p})$, weak (1 p), expressive ( $2 \mathrm{p})$; swelling - absent $(0 \mathrm{p})$, weak (1 p), covering all the gums around the tooth and the tooth-clear papillae ( $2 \mathrm{p}$ ), covers all the gums around the teeth, tooth-clear papillae and lip ( $3 \mathrm{p})$; erosive-necrotic changes - absent $(0 \mathrm{p})$, weak $(1 \mathrm{p})$, numerous $(2 \mathrm{p})$, numerous or large erosion $(3 \mathrm{~b})$. The condition of soft 


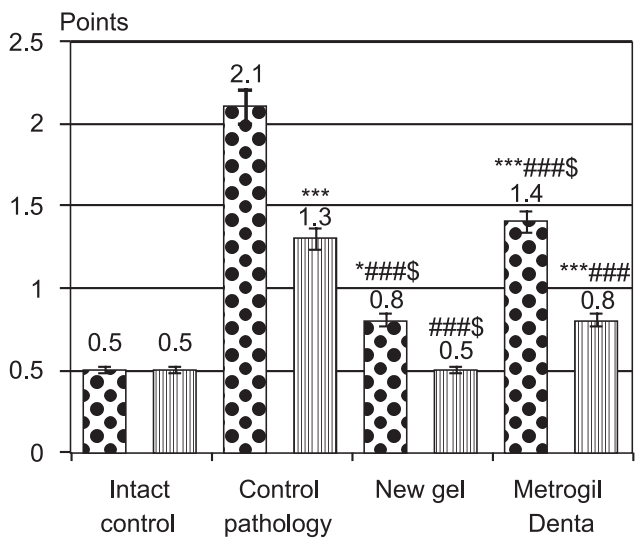

5 day 10 day

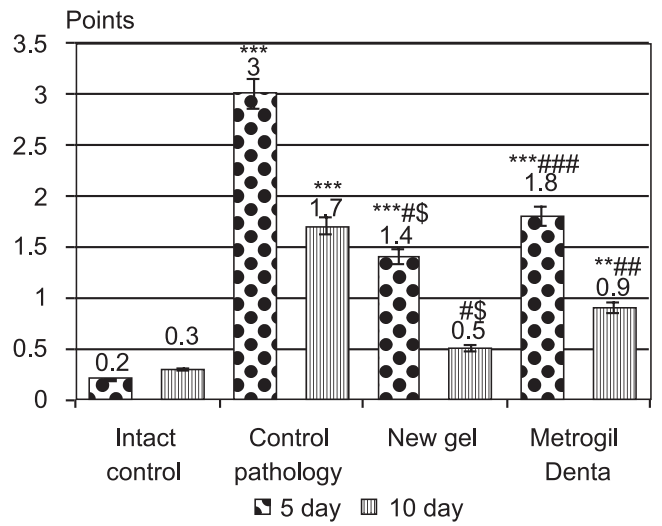

Notes: valid values for the group of intact controls $\left({ }^{*}-\mathrm{p}<0.05\right.$; ${ }^{* *}-\mathrm{p}<0.01$; $\left.{ }^{* *}-\mathrm{p}<0.001\right)$; valid values for the control pathology group (\#-p < 0.05; \#\#-p < 0.01; \#\#\#- p < 0.001); valid values for the comparison drug Metrogil Denta $(\$-p<0.05 ; \$-p<0.01 ; \$ \$-p<0.001)$.

Fig. 1. Clinical manifestations of experimental stomatitis: $\mathbf{A}$ - hyperemia of the mucous membrane of the oral cavity on the 5th and 10th day of the experiment; $\mathbf{B}$ - swelling of the mucous membrane of the oral cavity on the 5 th and 10th day of the experiment

tissues of periodontal disease was evaluated visually in the presence of a clear groove - absent $(0 \mathrm{~b})$, weak $(1 \mathrm{~b})$, expressive (2 b) [10].

The intensity of the development of the inflammatory process and the character and systemicity of the pathology were estimated at 5th and 10th day, with changes in the following parameters: leukocytes and erythrocyte sedimentation rate (ESR). Animals were taken out from the experiment at 10th day and their biomaterials (blood, tongue) were collected to determine the LPO/AOP system (catalase, thiobarbituric acid reactive substances (TBARS), recovered glutathione (RG). Statistical processing was performed by using variation of statistics methods by using the StatPlus 6 program package [11]. The results are presented in the form of an average and its standard error for parametric indicators.

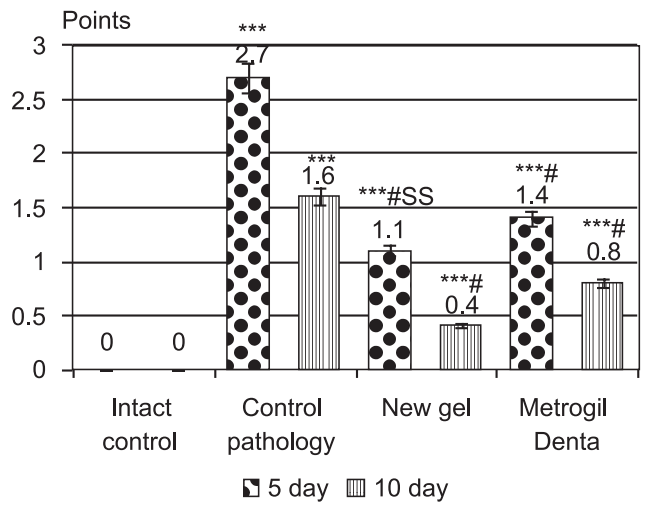

A

\section{RESULTS AND DISCUSSION}

Clinical manifestations of experimental stomatitis, the effect of a new gel which contains oak bark extract and aloe extract and comparison drug Metrogyl Denta is shown in Fig. 1-2.

In animals of the $\mathrm{CP}$ group, experimental stomatitis was characterized by significant clinical manifestations. At the 5th day of the study, significant hyperemia of the mucous membrane of the mouth ( $2.1 \mathrm{p})$, edema ( $3 \mathrm{p}$ ), erosive-necrotic changes ( $2.7 \mathrm{p})$, increase in the severity of the ascetic groove (2.3 p); On the 10th day of the study, these indicators had some tendency to decrease, but remained extremely high (1.3p-1.7p-1.6p-1.3p, respectively).

Animals which received treatment with a new gel, had a strong activation of the reparative processes of oral mucosa, which was verified by a significant decrease

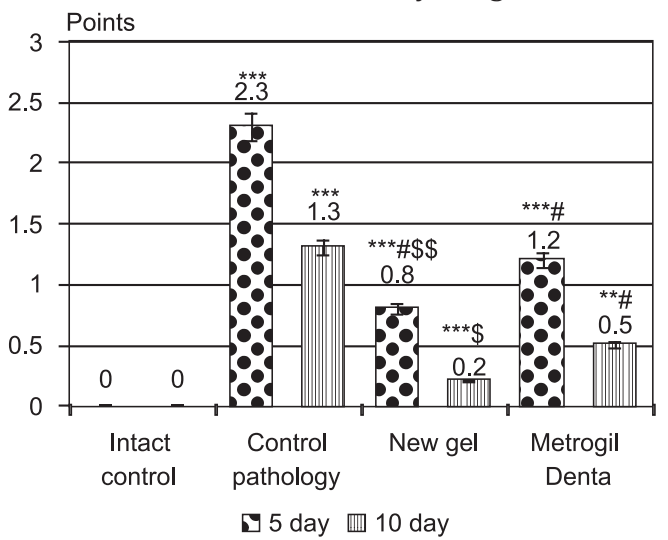

B

Notes: valid values for the group of intact controls $\left(^{*}-\mathrm{p}<0.05 ;{ }^{* *}-\mathrm{p}<0.01 ;{ }^{* *}-\mathrm{p}<0.001\right.$ ); valid values for the control pathology group (\#-p $<0.05 ; \# \#-p<0.01$; \#\#\#- p < 0.001); valid values for the comparison drug Metrogil Denta $(\$-p<0.05 ; \$-p<0.01 ; \$ \$-p<0.001)$.

Fig. 2. Clinical manifestations of experimental stomatitis: $\mathbf{A}$ - erosive-necrotic changes of the mucous membrane of the oral cavity on the 5th and 10th day of the experiment; $\mathbf{B}-$ the state of the clear groove on the 5 th and 10th day of the experiment 
Table 1

INVESTIGATED INFLUENCE ON THE PARAMETERS OF ESR AND LEUKOCYTES UNDER THE CONDITIONS OF EXPERIMENTAL STOMATITIS ( $n=8$, IN A GROUP)

\begin{tabular}{|c|c|c|c|c|}
\hline \multirow{2}{*}{ Group } & \multicolumn{2}{|c|}{$\mathrm{ESR}, \mathrm{mm} / \mathrm{h}$} & \multicolumn{2}{|c|}{ Leucocytes, $10^{9} / 1$} \\
\hline & 5 day & 10 day & 5 day & 10 day \\
\hline Intact control & $1.51 \pm 0.06$ & $1.48 \pm 0.03$ & $9.21 \pm 0.10$ & $9.20 \pm 0.05$ \\
\hline New gel & $3.05 \pm 0.19^{\text {*\#\# }}$ & $1.97 \pm 0.06^{* \# \#}$ & $16.2 \pm 1.16^{* \#}$ & $10.4 \pm 0.59^{\# \#}$ \\
\hline Metrogil Denta & $3.50 \pm 0.08^{\text {*\#\# }}$ & $2.21 \pm 0.09^{* \# \#}$ & $14.6 \pm 0.26^{* \# \#}$ & $11.1 \pm 0.29$ *\#\# \\
\hline
\end{tabular}

Notes: valid values for the group of intact controls $(*-p<0.001)$; valid values for the group of control pathology group $(\#-\mathrm{p}<0.05 ; \#-\mathrm{p}<0.001)$.

in the intensity of clinical manifestations of stomatitis (Fig. 1-2). At 5 th day of the experimental stomatitis in the NG group there was a decrease in the hyperemia of the oral mucosa in 2.6 times, edema in 2.1 times, erosive-necrotic phenomena in 2.4 times, a decrease in the severity of the ascetic groove in 2.9 times. On the 10th day of development of pathology, the indicated indicators were as close as possible to the indices in intact rats.

Applying comparison drug Metrogyl Denta on the mucous membrane of the oral cavity, damaged by solution of sodium hydroxide, it reduce the clinical manifestations of stomatitis in comparison to the group of rats in the control pathology, but was significantly inferior to the new gel.

The higher efficiency of a new gel in the treatment of stomatitis can be explained by its complex composition. Biologically active substances of the aloe extract and oak bark extract, as is known from the literature and from our previous studies, have a pronounced anti-inflammatory, membrane protector, reparative action and prevent the development of infection of affected areas due to antibacterial activity [12].

Metrogyl denta contains metronidazole benzoate, which have antiprosenic and antimicrobial activity and chlorhexidine gluconate, an antiseptic of bactericidal action, active in a wide range of vegetative forms of gramnegative and gram-positive microorganisms, dermatophytes and lipophilic viruses. The reparative and membrane protectivity action of Metrogyl Denta is significantly inferior to its effectiveness of the new gel.

The fact that the experimental pathology acquired a systemic character is evidenced by the development of leukocytosis in animals of the control group (Tab. 1). At 5 th day in animals of the control group, the number of leukocytes was 2.2 times higher than the physiological level (intact animals) at 10th days - 1.6 times. The ESR measure against the background of experimental stomatitis in untreated animals on the 5th and 10th day exceeded the data of intact animals at 3.2 and 2.2 times, respectively. The indicated changes characterize the expressed inflammatory and systemic flow of stomatitis.

The application of a new gel which contains oak bark extract and aloe extract in the treatment regimen contributed to a possible decrease in ESR and leukocyte parameters on the 5th and 10th day of the experiment in relation to the control group. It should be noted that due to the effect on the ESR and the content of leukocytes, as markers of the systemic inflammatory process, the new gel exceeded the effectiveness of the comparison drug Metrogil Denta.

The stomatitis was characterized by a significant violation of the balance of the LPO-AOP (Tab. 2).

Changes in the antioxidant system of animals with stomatitis is indicated by an increase of 2 times the TBARS in the blood serum, an increase of this index by $52 \%$ in the tongue homogenate and a decrease in both the enzymatic and non-enzymatic activity of the endogenous AOP system, verified by the decrease in the activity of catalase at $21 \%(\mathrm{p}<0.05)$, reduced glutathione by $42 \%$.

The new gel produced a potent antioxidant effect with a significant decrease relative to the group of cont rol pathology of LPO products, namely TBARS in blood serum and homogenate of the tongue in 1.8 and 1.4 times,

Table 2

\section{INVESTIGATED INFLUENCE ON THE INDICATORS OF BALANCE OF LPO-AOP IN CONDITIONS OF EXPERIMENTAL STOMATITIS ( $\mathrm{n}=\mathbf{8}$, IN A GROUP)}

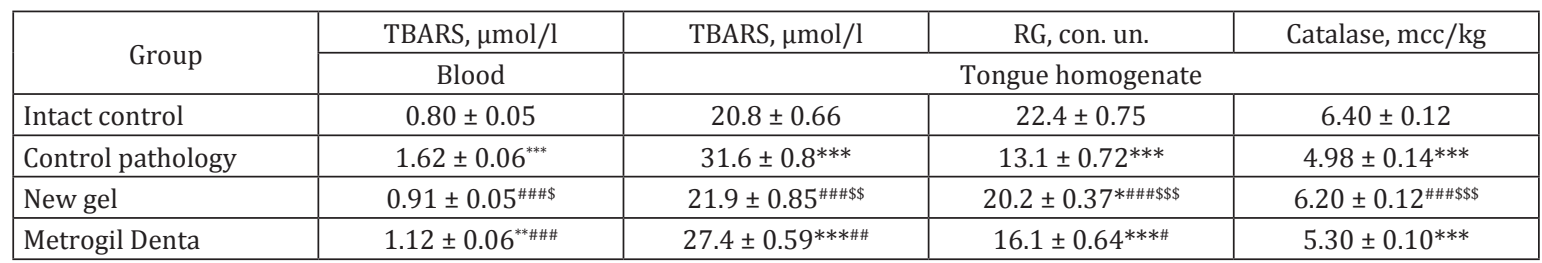

Notes: valid values for the group of intact controls $\left({ }^{*}-\mathrm{p}<0.05\right.$; $^{* *}-\mathrm{p}<0.01$; *** $\left.-\mathrm{p}<0.001\right)$; valid values for the control pathology group $\left(\#-p<0.05 ;{ }^{\# \#}-p<0.01\right.$; \#\#\# - p $\left.<0.001\right)$; valid values for the comparison drug Metrogil Denta $\left(\$-p<0.05 ;{ }^{\$}-p<0.01 ;{ }^{\$ \$ \$}-p<0.001\right)$. 
respectively, and the normalization of endogenous antioxidant defense - an increase in the content of RG by $35 \%$, activity of catalase by $19 \%$.

The Metrogyl Denta by the influence on the balance of the POL-AOS was significantly inferior to the new gel, this can be explained by the fact that biologically active substances of the oak bark extract and aloe extract have an anti-propagation effect, are directly catchs free radicals and activate AOP system.

\section{CONCLUSIONS}

1. The application of a $10 \%$ sodium hydroxide solution to the mucous membrane of the lower shear of scrubs induces the development of a chronic destructive-inflammatory process, which according to clinical signs can be classified as a stomatitis, which from 5 days acquires the nature of systemic inflammation.
2. The application of a new gel, which contains oak bark extract and aloe extract in the treatment, contributed to the normalization of clinical and biochemical parameters, reduction of severity of destructive-inflammatory changes and more rapid healing of the oral mucosa.

3. By reducing hyperemia, edema, erosive-necrotic formations, the severity of the ashen groove, the new gel is likely to exceed the comparative drug Metrogil Denta, which is due to the presence of a new gel powerful antioxidant action.

4. The new gel, which contains oak bark extract and aloe extract, is found to be an effective remedy for the treatment of experimental stomatitis, can be considered promising for further research and implementation into medical practice.

Conflicts of Interests: authors have no conflict of interest to declare.

\section{REFERENCES}

1. Rapid quantification of vesicular stomatitis virus in Vero cells using Laser Force Cytology / C. G. Hebert, N. DiNardo, Z. L. Evans et al. // Vaccine. 2018. - Vol. 36 (41). - P. 6061-6069. https://doi.org/10.1016/j.vaccine.2018.09.002

2. Miller, A. L. Integral characteristics of infectious and inflammatory diseases of the mouth / A. L. Miller, I. M. Long, G. E. Hrystyan // Clinical and Experimental Patolohiya. - 2015. - T. XIV, № 1 (51). - P. 215-220.

3. Epidemiology of oral mucosal lesions in Slovenia / A. A. Kansky, V. Didanovic, T. Dovsak et al. // Radiol. Oncol. - 2018. - № 52. - P. 263-266. https://doi.org/10.2478/raon-2018-0031

4. Management of afatinib-induced stomatitis / S. Kato, A. Saito, N. Matsuda et al. // Mol. Clin. Oncol. - 2017. - № 4. - P. 603-605. https://doi. org/10.3892/mco.2017.1184

5. Sonis, S. On the pathogenesis of mTOR inhibitor-associated stomatitis (mIAS)-studies using an organotypic model of the oral mucosa / S. Sonis, P. W. Andreotta, G. Lyng // Oral Dis. - 2017. - № 3. - P. 347-352. https://doi.org/10.1111/odi.12616

6. Zhang, Z. Enzymatic antioxidants in patients with recurrent aphthous stomatitis / Z. Zhang, S. Li, H. Fang // J. Oral Pathol. Med. - 2017. - № 46 (9). P. 817-820. https://doi.org/10.1111/jop.12547

7. Different modalities for the treatment of recurrent aphthous stomatitis. A Randomized clinical trial / S. A. Nasry, H. M. El Shenawy, D. Mostafa et al. // J. Clin. Exp. Dent. - 2016. - № 5. - P. 517-522. https://doi.org/10.4317/jced.52877

8. Comparative efficacy of Aloe vera and Benzydamine Mouthwashes on Radiation-Induced Oral Mucositis: A Triple-blind, Randomised, Controlled Clinical Trial / M. Sahebjamee, A. Mansourian, M. Hajimirzamohammad et al. // Oral Health Prev. Dent. - 2015. - № 4. - P. 309-315. https://doi. org/10.3290/j.ohpd.a33091

9. The effect of Aloe Vera Solution on Chemotherapy-Induced Stomatitis in Clients with Lymphoma and Leukemia: A Randomized Controlled Clinical Trial / P. Mansouri, M. Haghighi, N. Beheshtipour et al. // Int. J. Community Based Nurs Midwifery. - 2016. - № 2. - P. $119-126$.

10. Стефанів, І. В. Дослідження лікувальної дії стоматологічної настойки «Касдент» на моделі стоматиту у щурів / І. В. Стефанів, Л. В. Яковлєва, С. А. Гращенкова // Клін. фармація, фармакотерапія та мед. стандартизація. - 2014. - № 1-2. - С. 23-29.

11. StatPlus // AnalystSoft Inc. - Режим доступу : www.analystsoft.com/ru

12. Screening Study for Finding the Optimal Combination Gel Composition for the Treatment of Periodontal Disease., Which Contains Extracts of Aloe Vera and Oak Bark / N. A. Tsubanova, D. S. Zhurenko, N. V. Khokhlenkova, T. O. Artiukh // Asian J. of Pharmaceutics. - 2017. - Vol. 11 (2). - P. $353-357$.

\section{REFERENCES}

1. Hebert, C. G., DiNardo, N., Evans, Z. L., Hart, S. J., \& Hachmann, A.-B. (2018). Rapid quantification of vesicular stomatitis virus in Vero cells using Laser Force Cytology. Vaccine, 36 (41), 6061-6069. https://doi.org/10.1016/j.vaccine.2018.09.002

2. Miller A. L., Long I. M., Hrystyan G. E. (2015) Integral characteristics of infectious and inflammatory diseases of the mouth. Clinical and Experimental patolohiya, 14 (1 (51)), 215-220.

3. Kansky, A. A., Didanovic, V., Dovsak, T., Brzak, B. L., Pelivan, I., \& Terlevic, D. (2018). Epidemiology of oral mucosal lesions in Slovenia. Radiology and Oncology, 52 (3), 263-266. https://doi.org/10.2478/raon-2018-0031

4. Kato, S., Saito, A., Matsuda, N., Suzuki, H., Ujiie, M., Sato, S., ... Satoh, H. (2017). Management of afatinib-induced stomatitis. Molecular and Clinical Oncology, 6 (4), 603-605. https://doi.org/10.3892/mco.2017.1184

5. Sonis, S., Andreotta, P., \& Lyng, G. (2017). On the pathogenesis of mTOR inhibitor-associated stomatitis (mIAS)-studies using an organotypic model of the oral mucosa. Oral Diseases, 23 (3), 347-352. https://doi.org/10.1111/odi.12616

6. Zhang, Z., Li, S., \& Fang, H. (2017). Enzymatic antioxidants status in patients with recurrent aphthous stomatitis. Journal of Oral Pathology \& Medicine, 46 (9), 817-820. https://doi.org/10.1111/jop.12547

7. Nasry, S., El Shenawy, H., Mostafa, D., \& Ammar, N. (2016). Different modalities for treatment of recurrent aphthous stomatitis. A Randomized clinical trial. Journal of Clinical and Experimental Dentistry, 5, 517-522. https://doi.org/10.4317/jced.52877

8. Sahebjamee M., Mansourian A., Hajimirzamohammad M., Zadeh, M. T., Bekhradi, R., ... Doroudgar, K. (2015) Comparative efficacy of Aloe vera and Benzydamine Mouthwashes on Radiation-Induced Oral Mucositis: A Triple-blind, Randomised, Controlled Clinical Trial. Oral Health Prev Dent., 4, 309-315. https://doi.org/10.3290/j.ohpd.a33091

9. Mansouri P., Haghighi M., Beheshtipour N., Ramzi, M. (2016) The effect of Aloe Vera Solution on Chemotherapy-Induced Stomatitis in Clients with Lymphoma and Leukemia: A Randomized Controlled Clinical Trial. Int J Community Based Nurs Midwifery, 4 (2), 119-126.

10. Stefaniv, I. V., Yakovlieva, L. V., Hrashchenkova, S. A. (2014). Klinichna farmatsiia, farmakoterapiia ta medychna standartyzatsiia, 1-2, 23-29.

11. StatPlus. (n.d.). AnalystSoft Inc. Available at: www.analystsoft.com/ru

12. Zhurenko, D. S., Tsubanova, N. A., Khokhlenkova, N. V., Artiukh, T. O. (2017). Screening Study for Finding the Optimal Combination Gel Composition for the Treatment of Periodontal Disease, Which Contains Extracts Of Aloe Vera And Oak Bark. Asian Journal of Pharmaceutics, 11(2), 353-357. 
Information about authors:

Tsubanova N., Doctor of Pharmaceutical Sciences, Professor, Department of General Pharmacy and Safety of drugs, Institute of Pharmacy Professionals Qualification Improvement of National University of Pharmacy. ORCID: https://orcid.org/0000-0002-9122-8291

Zhurenko D., postgraduate student of the Department of General Pharmacy and Safety of drugs, Institute of Pharmacy Professionals

Qualification Improvement, National University of Pharmacy. E-mail: zidikor@gmail.com. ORCID: https://orcid.org/0000-0002-5555-1091

Відомості про авторів:

Цубанова Н. А., д-р фарм. наук, професор кафедри загальної фармації та безпеки ліків, Інститут підвищення кваліфікації спеціалістів фармації Національного фармацевтичного університету. ORCID: https://orcid.org/0000-0002-9122-8291

Журенко Д. С., аспірант кафедри загальної фармації та безпеки ліків, Інститут підвищення кваліфікації спеціалістів фармації

Національного фармацевтичного університету. E-mail: zidikor@gmail.com. ORCID: https://orcid.org/0000-0002-5555-1091

Сведения об авторах:

Цубанова Н. А., д-р фарм. наук, профессор кафедры общей фармации и безопасности лекарств, Институт повышения квалификации специалистов фармации Национального фармацевтического университета. ORCID: https://orcid.org/0000-0002-9122-8291

Журенко Д. С., аспирант кафедры общей фармации и безопасности лекарств, Институт повышения квалификации специалистов

фармации Национального фармацевтического университета. E-mail: zidikor@gmail.com. ORCID: https://orcid.org/0000-0002-5555-1091

Надійшла до редакції 10.10 .2018 р. 